\title{
Benefits of Music Therapy in the Quality of Life of Older Adults
}

\section{Beneficios de la musicoterapia en la calidad de vida de los adultos mayores}

\section{Benefícios da musicoterapia na qualidade de vida dos idosos}

Veronika Diaz Abrahan, $\mathrm{PhD}^{1 *}$

Anahi Lemos Jaramillo, Lic. ${ }^{2}$

Nadia Justel, $\mathrm{PhD}^{3}$

Received: April 02, 2019 - Accepted: July 22, 2019

Doi: http://dx.doi.org/10.12804/revistas.urosario.edu.co/revsalud/a.8349

To quote this article: Diaz Abrahan V, Lemos Jaramillo A, Justel N. Benefits of Music Therapy in the Quality of Life of Older Adults. Rev Cienc Salud. 2019;17(3):9-19. Doi: http://dx.doi.org/10.12804/revistas.urosario.edu.co/revsalud/a.8349

\section{Abstract}

Introduction: Aging is a complex, universal and irreversible process, with gradual changes that fluctuate from one person to another due to several factors (physiological, biological, environmental, social etc.). There are precedents for the potential effect of music therapy on psychological and social aspects which are characteristic of the elderly. In this sense, the aim of this work is to evaluate the effectiveness of music therapy in improving the quality of life of older adults. Materials and Methods: A quality of life inventory was administered, comparing a group that attended a music therapy stimulation and a control group that did not have this type of stimulus. Results: Music therapy attendees had higher scores in terms of total quality of life and subcomponents of the inventory (religion, creativity, recreation and love). Conclusion: The music therapy approach, with its non-invasive techniques, presents a proposal with potential benefits to improve the quality of life of the elderly.

Keywords: Aging, quality of life, music therapy, older adult.

1 Laboratorio Interdisciplinario de Neurociencia Cognitiva. Centro de Estudios Multidisciplinarios en Sistemas Complejos y Ciencias del Cerebro. Escuela de Ciencia y Tecnología, Universidad Nacional de San Martín (Buenos Aires, Argentina). Consejo Nacional de Investigaciones Científicas y Tecnológicas.

Autor de correspondencia: abrahanveronika@conicet.gov.ar

2 Universidad Nacional de Buenos Aires (Argentina).

3 Laboratorio Interdisciplinario de Neurociencia Cognitiva. Centro de Estudios Multidisciplinarios en Sistemas Complejos y Ciencias del Cerebro. Escuela de Ciencia y Tecnología, Universidad Nacional de San Martín (Buenos Aires, Argentina). Consejo Nacional de Investigaciones Científicas y Tecnológicas. 


\section{Resumen}

Introducción: el envejecimiento es un proceso complejo, universal e irreversible, con cambios graduales que fluctúan de un individuo a otro por diversos factores (fisiológicos, biológicos, ambientales, sociales, etc.). Existen antecedentes del efecto potencial de la musicoterapia sobre aspectos psicológicos y sociales característicos de las personas de la tercera edad. En ese sentido, el objetivo del presente trabajo es evaluar la eficacia de la musicoterapia para mejorar la calidad de vida de los adultos mayores. Materiales y métodos: se administró un inventario de calidad de vida, comparando un grupo que asistía a un taller de musicoterapia y un grupo control que no tenía este tipo de estimulación. Resultados: los asistentes a musicoterapia presentaron mayores puntajes en lo que refiere a la calidad de vida total y en subcomponentes del inventario (religión, creatividad, recreación y amor). Conclusión: el abordaje musicoterapéutico, con sus técnicas no invasivas, presenta una propuesta con potenciales beneficios para mejorar la calidad de vida de los adultos mayores.

Palabras clave: envejecimiento, calidad de vida, musicoterapia, adultos mayores.

\section{Resumo}

Introdução: o envelhecimento é um processo complexo, universal e irreversível, com mudanças graduais que flutuam de um indivíduo a outro por diversos fatores (fisiológicos, biológicos, ambientais, sociais, etc.). Existem antecedentes do efeito potencial da musicoterapia sobre aspetos psicológicos e sociais característicos das pessoas idosas. Neste sentido, o objetivo do presente trabalho é avaliar a eficácia da musicoterapia para melhorar a qualidade de vida dos idosos. Materiais e métodos: se administrou um inventário de qualidade de vida, comparando um grupo que assistia a um curso de musicoterapia e um grupo controle que não tinha este tipo de estimulação. Resultados: os assistentes à musicoterapia apresentaram maiores pontuações no que refere à qualidade de vida total e em subcomponentes do inventário (religião, criatividade, recreação e amor). Conclusão: a abordagem musico-terapêutica, com suas técnicas não invasivas, apresenta uma proposta com potenciais benefícios para melhorar a qualidade de vida dos idosos.

Palavras-chave: envelhecimento, qualidade de vida, musicoterapia, idosos.

\section{Introduction}

rom a demographic point of view, since the second half of the $20^{\text {th }}$ century, aging popu-
lation is a process characterized by the increase in the proportion of elderly persons (above 65 years old), at a global level, that results in the demographic transition, starting from an initial situation of high fertility and mortality indexes to an stage in which both indexes show low levels (1). In this context, it is necessary to produce health promotion and prevention policies aiming at improving life expectancy and quality of population (2).

Aging is a universal phenomenon, present in all ages and cultures (3). It is a dynamic and continuous process that depends on several factors that are not isolated from each other and occur dissimilarly in each individual, according to the modes or lifestyles, and social and environmental surrounding. Therefore, due to this complexity of the aging individual, it is necessary to study the issue from the interdisciplinary approach (4).

From a psycho-gerontological approach there are three types of aging: normal, pathological and active aging (4). The first one refers to the natural changes occurring in the absence of a disease, as a result of the constant modifications along an individual's course 
of life, characterized by a certain degree of natural decline of cognitive functions such as memory, visual spatial capacities and the information processing speed (5). Pathological aging has to do with changes produced by illnesses or bad habits that are not part of normal aging. Sometimes, it can be prevented or controlled, while in some others it is irreversible, as in the case of some dementia, neurodegenerative disorders, Alzheimer's disease, frontal-temporal dementia, and dementia associated to Parkinson's disease, among others (5, 6). Finally, active aging takes place in the best possible (physical, psychological and social) conditions, it entails few - or none- losses of the psychosocial, physical and/or cognitive abilities, resulting in a better quality of life and life expectancy (5). Therefore, it implies and directly depends on certain environmental factors such as physical exercise (7), adequate nutrition (8), educational level (9), social and leisure activities (10), promotion of alternative, non-pharmacological therapies, among others (11).

Among the non-pharmacological proposals aiming at raising the quality of life of older people for the purpose of promoting healthy aging or approaching a pathological aging, there is music therapy (мт) (3). There are precedents for the effectiveness of мт in raising quality of life of elderly with and without cognitive impairment, as well as in the general population (12), since positive results of variables such as behavioral disorders $(13)$ or anxiety $(14,15)$ have been established. However, there are other variables analyzed by researches that present contradicting results or moderate effects showing trends rather than statistical indicators, such as symptoms of depression $(16,17)$ or quality of life indicators $(13-18)$. Nevertheless, it should be noted that researches carried out so far focus on patients with dementia, in this sense, the question about the effect of music therapeutic stimulation in other dimensions arises, such as quality of life of elderly. In order to address the research question, in the present study, the objective of determining the scope of the impact of мт on older adults was addressed. Considering the exposed precedents, it is expected that the individuals participating in activities of music therapy will present higher levels of quality of life than volunteers who did not participate in this proposal.

\section{Materials and Methods}

Thirty elderly patients (73\% women) over the age of 60 years (M: 76.90, sD: 1.9) participated 1 in this study. It was governed according to the existing ethical standards (19). Participants were asked to sign a consent form in which the purposes of the study and the commitment to ensure anonymity and confidentiality of data were outlined in detail.

Participants were separated into two groups according to having attended or not the program of music therapy at the day center of the autonomous city of Buenos Aires. In this way, there were 15 volunteers who participated in the мт program (experimental group) for 
a period of eight months. The program proposed by the day center aimed at dealing with the psychosocial problems of older persons, encouraging integration among peers, self-management, and social participation. On a weekly basis of two hours per meeting, activities of free or assigned music improvisation, the use of easy handling musical instruments, as well as by means of working with selected songs in accordance with the addressed topic in the session, and rhythm-auditive activities using percussion instruments.

On the other hand, the control group was comprised of 15 volunteers who did not take part in activities of music therapy, nor in recreational activities and/or cognitive stimulation offered in the day centers.

As for the conducted procedure, the study involved one single day for assessment, with a duration of approximately 15 to 20 minutes. In the first instance, sociodemographic data of the participants was collected by means of a questionnaire concerning personal information such as name, last name, gender, marital status, education level, nationality, and occupation. Subsequently, the assessment of the participant's quality of life was carried out, a task that was carried out on an individual base.

For measuring quality of life, the inventory of quality of life (IQoL) was used, which is internationally validated (20) and assesses different areas of life (health, self-esteem, values, religion, finances, work, recreation, education, creativity, solidarity, love, friends, children, relatives, home, neighborhood, community, and environment) in level of importance (unimportant, important, very important) and satisfaction (dissatisfied to satisfied). It is applicable to persons in any age group. Initially, the IQoL instructions were presented with the purpose of making the evaluated individuals understand the instructions and they were given an example of the task. Subsequently, the definition of each area was read in order to avoid any confusion. Finally, the IQoL was implemented. For instance, the individual in assessment was asked how important was health for him/her (the respondent answered in a scale of Unimportant, Important or Very Important). Then the question was on how satisfied was he/she with his/her health, for the answer the participant could choose dissatisfied (very, greatly or slightly) or satisfied (slightly, very, greatly). This was the procedure for all 18 areas assessed by the inventory.

With the gathered data, a final scoring for each participant was obtained: each area was rated in terms of importance and satisfaction. The importance level was rated between 0 and 2, where 0 was Unimportant, 1 Important, and 2 Very Important. The dissatisfaction/ satisfaction level was assessed between -3 (Dissatisfied -3, -2, -1) and 3 (Satisfied 1, 2, 3). Afterwards, the Importance level was multiplied by the Satisfaction level, producing a raw result or raw score for each assessed area.

In order to obtain the total index of quality of life, the raw scores obtained in each area were averaged. Finally, the average and standard deviation were calculated by group (мт and CTRL), as well as the percentiles. As to the IQoL in terms of percentiles, total quality of life of a person can be classified as: 
- High: Persons who show high IQoL percentiles, who perceive themselves as happy in their daily life, and are not under psychological distress.

- Average: People over percentiles 28 and 50, present no psychological distress and have important psychosocial resources.

- Low: People presenting a percentile between 1 and 27, characterized by being relatively unhappy, who are at risk of presenting psychological and health problems in the future. Finally, a statistical analysis with spss Statistics 17.0.2 software was conducted, using the Student's $t$ test for independent samples, where the IQoL life areas were the dependent variables (health, self-esteem, values, religion, finances, work, recreation, education, creativity, solidarity, love, children, relatives, home, neighborhood, community, and environment); and the group (мт Vs. стRL) the independent variable. A significance level of .05 was considered acceptable.

\section{Results}

$\mathbf{R}_{\text {who participated of мт activities (experimental group), with an average age of } 80 \text { years old; }}^{\text {egarding the sociodemographic characteristics, the final sample consisted of } 15 \text { volunteers }}$ $73 \%$ were widowed, all with Argentine nationality, and all retirees. On the other hand, the control group consisted of 15 volunteers, with an average age of 73 years old, $46 \%$ of them were widowed and 54\% were married, all with Argentine nationality and retirees.

More specifically, as for the measurement results of quality of life, the persons participating in a proposal of music therapy showed higher scores concerning the total quality of life, encompassing the final average of all life areas of the inventory (figure 1). This impression was corroborated by the statistical analysis that showed significant differences by group regarding this variable: $t(28)=3.73, p<.001$.

The positive difference of the group of elderly participating in activities of music therapy is strengthened by the interpretations of the results referring to the percentiles obtained for the total quality of life, according to the established standards (20) (table 1). This way, it can be observed that, out of the total of 15 persons of the мт group, $86.6 \%$ show a high classification, while in the crRL group there is a representation of $46.6 \%$ in this category. 


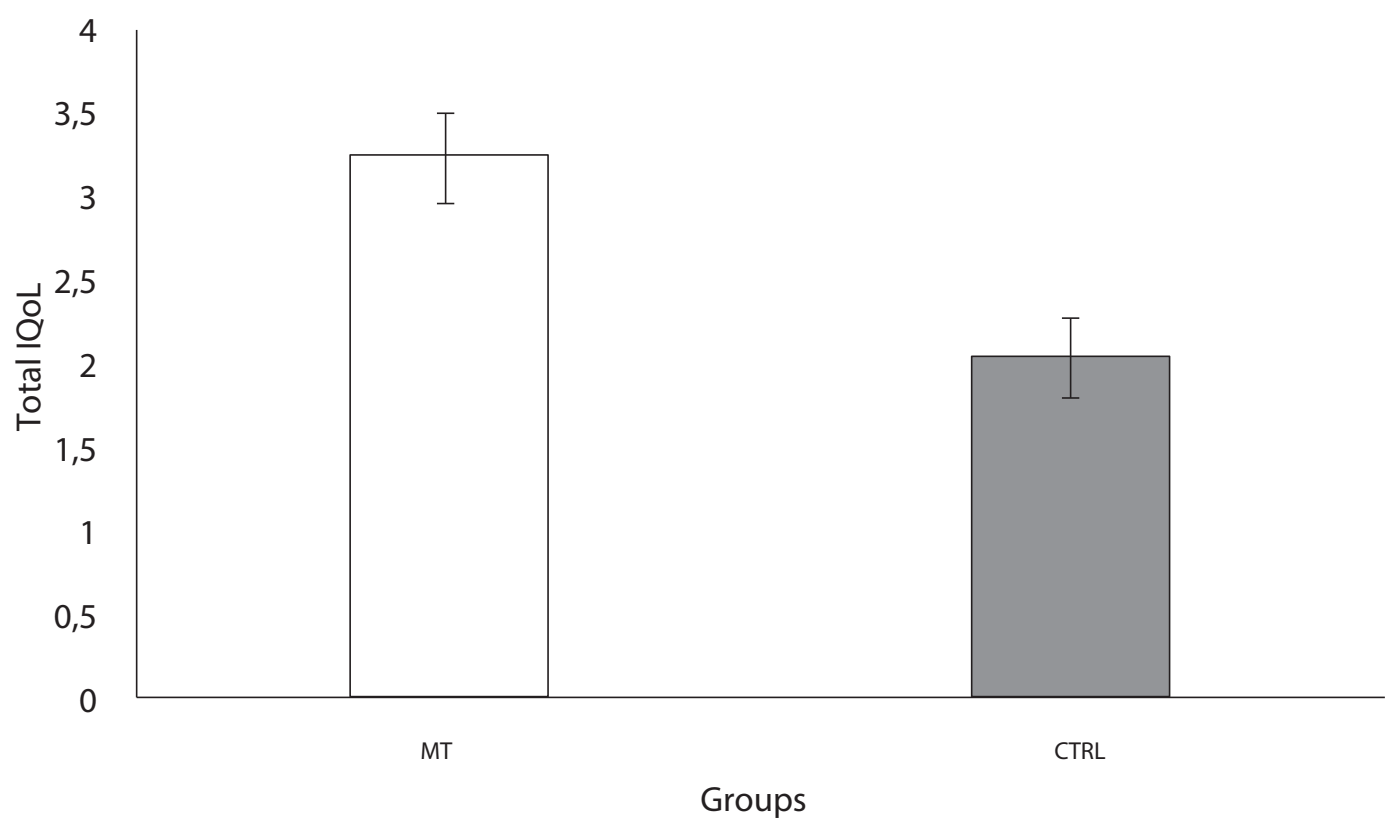

Figure 1. Total Quality of Life

Average value of the different assessed areas of Total Quality of Life for the group participating in activities of music therapy (мт), and the group not attending these activities (стRL). Vertical lines represent the standard error.

Table 1. Total Quality of Life of the percentile of each assessed individual, by group

\begin{tabular}{ccccc}
\hline \multicolumn{3}{c}{ MT } & \multicolumn{2}{c}{ CTRL } \\
\hline Individual & Percentile & Classification & Percentile & Classification \\
\hline 1 & 50 & High & 61 & High \\
2 & 61 & Average & 21 & Low \\
3 & 29 & Average & 71 & High \\
4 & 68 & High & 9 & Low \\
5 & 71 & High & 68 & High \\
6 & 68 & High & 29 & Average \\
7 & 50 & High & 23 & Low \\
8 & 91 & High & 35 & Average \\
9 & 75 & High & 21 & Low \\
10 & 75 & High & 23 & Low \\
11 & 55 & High & 11 & Low \\
12 & 96 & High & 35 & Average \\
13 & 97 & High & 23 & Low \\
14 & 85 & High & 61 & High \\
15 & 21 & Low & 55 & High \\
\hline
\end{tabular}

Note: Classification: Low (percentile between 1 and 27), Average (percentile greater than 28), High (values greater than 50).

MT: Individuals receiving music therapy stimulation.

CTRL: Individuals not attending this stimulation. 
Regarding the partial assessment by each area of life evaluated by the inventory, statistically significant differences were found in the areas of religion $t(28)=2.06 ; p<.05$ (referring to the set of feelings and believes people profess in their relation with divinity); recreation $t(28)=$ $4.80, p<.001$ (concerning what everyone does in his/her spare time for having fun, relaxing or gratifying); creativity $t(28)=2.27, p=<.05$ (related to the use of imagination for finding new and more intelligent ways of solving daily problems, or having a hobby); and love $t(28)=3.21, p=$ .003 (referring to close and romantic relations with other people) (figure 2). No differences in the areas of health, self-esteem, values, finances, work, education, solidarity, friends, relatives, home, neighborhood, community, environment and children were found (table 2).

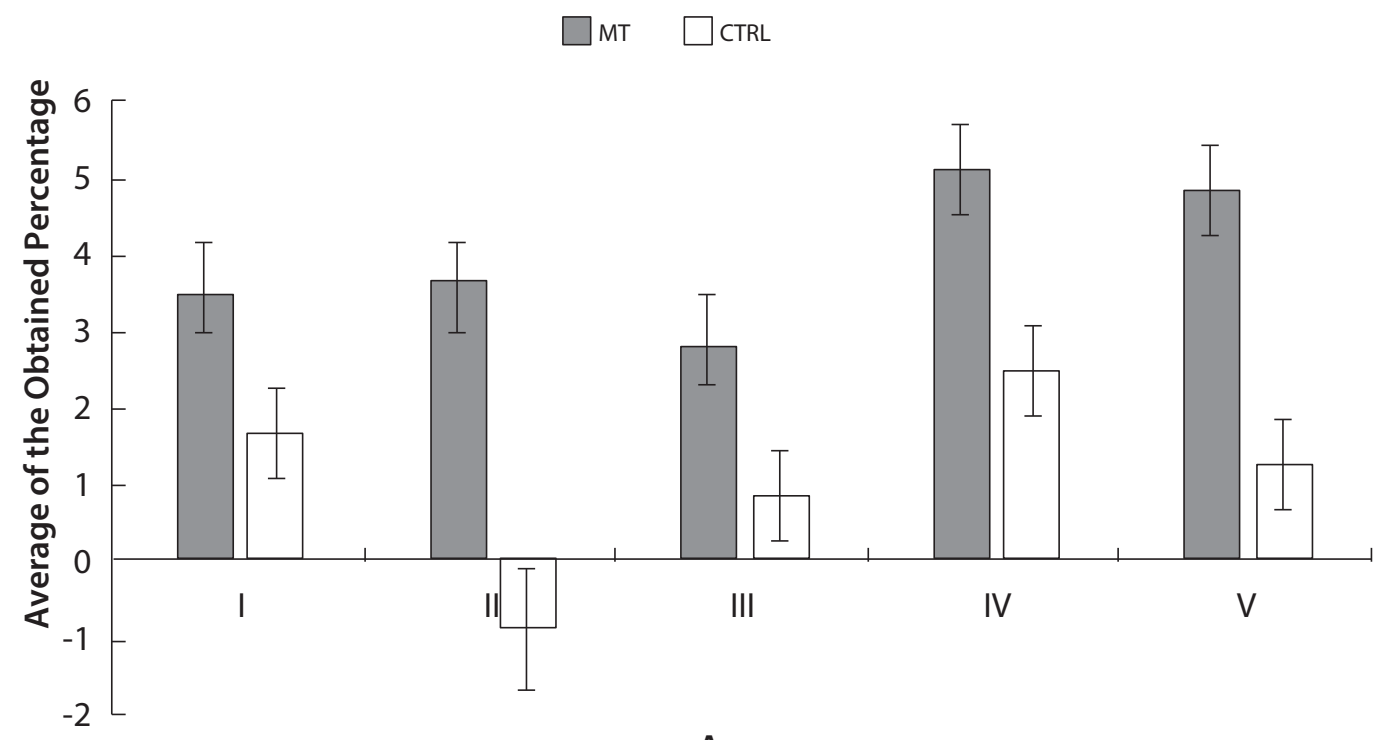

Areas

Figure 2. Areas of the IQoL that presented significant differences by group (MT VS. CTRL)

Note: I: Religion; II: Recreation; III: Creativity; IV: Solidarity; V: Love.

Vertical lines represent the standard error.

Table 2. IQoL areas of life not showing significant differences

\begin{tabular}{cccccc}
\hline & \multicolumn{3}{c}{ MT } & \multicolumn{2}{c}{ CTRL } \\
\hline $\begin{array}{c}\text { Area of Life } \\
\text { Area }\end{array}$ & $\boldsymbol{M}$ & $\boldsymbol{S D}$ & $\boldsymbol{M}$ & $\boldsymbol{S D}$ & $\boldsymbol{p}$ \\
\hline Health & 2.6 & .9 & .6 & 1.1 & .16 \\
Self Esteem & 3.8 & .3 & 2.0 & 1.2 & .16 \\
Values & 4.1 & .4 & 3.9 & .4 & .81 \\
Finances & 1.5 & .5 & 1.5 & .4 & .95 \\
Work & 4.5 & .5 & 3.7 & .4 & .21 \\
Study & 2.6 & .8 & .8 & .8 & .14 \\
Friends & 2.6 & .6 & 3.9 & .6 & .13 \\
Children & 5.2 & .5 & 4.7 & .5 & .56 \\
\hline & & & & & (Continue)
\end{tabular}




\begin{tabular}{cccccc}
\hline & \multicolumn{2}{c}{ MT } & \multicolumn{2}{c}{ CTRL } \\
$\begin{array}{c}\text { Area of Life } \\
\text { Area }\end{array}$ & $\boldsymbol{M}$ & $\boldsymbol{S D}$ & $\boldsymbol{M}$ & $\boldsymbol{S D}$ & $\boldsymbol{p}$ \\
\hline Relatives & 3.5 & .8 & 3.3 & .7 & .83 \\
Home & 3.3 & .7 & 1.7 & .9 & .18 \\
Neighborhood & 1.6 & .5 & 1.4 & .6 & .17 \\
Community & 2.8 & .6 & 2.8 & .7 & .93 \\
Environment & .6 & .8 & 1.0 & 1.0 & .74 \\
\hline
\end{tabular}

Note: The table shows Mean (M), standard deviation (SD), and the significance values (p).

\section{Discussion}

Crowing old is a peculiar and specific stage in the course of life and implies a complex $\widetilde{J}$ process of relevant changes at bio-psycho-socio-cultural level (3). In this sense, it is necessary to address, in an interdisciplinary fashion, the person in the aging process in such a way that enables having a wide and deep knowledge about his/her generalities and particularities in order to optimally meet his/her needs, a fact that will eventually bring an improvement in his/her quality of life.

For this reason, the objective of this work was to explore the effect of the participation in а мт program for elderly, assessing the participants' quality of life. Our results showed that the benefits of music therapy were reflected in the total quality of life scores, encompassing the final average of all the inventory areas of life. Likewise, significant effects in subcomponents of the inventory were established, such as religion, recreation, creativity and love; but no significant results in health, self-esteem, values, finances, work, education, solidarity, friends, relatives, home, neighborhood, community, environment and children. This has partially proven our research assumption of the effects of music therapy stimulation in elderly's quality of life.

Even though findings are partial, they accompany the precedents highlighting a moderate effect by the techniques in мт (18). However, a point to emphasize in literature is heterogeneity respecting the technics and resources used in the researches, a fact that renders comparisons among the results of the studies difficult. It is pertinent to consider methodological designs and controlled procedures aiming to achieve replicability of results in order to reach concrete conclusions; an aspect that, in our study, has also proved to be worthy of criticism.

Emotional induction and increasing social interaction as a consequence of the participation in musical proposals could be the cause of the partial increase in quality of life. Concerning emotionality, it has been established that taking part in musical activities modulates emotions, thus producing positive affective states (21). On the other hand, there are empirical studies in neurosciences that have demonstrated that the caudate nucleus, a core 
area of the brain reward response system that fosters prosocial behavior in adults, increases its activity during activities of combined percussion (22). From a more basic analysis and in relation to neurochemical components, oxytocin and vasopressin, two neuropeptides known for regulating social behavior (23), increase their concentration during involvement in interactive musical activities, thus affecting social bonding and affiliation (24). However, in order to arrive at concrete conclusions, studies including physiological and behavioral measures of pre and post treatment in music therapy should be made available.

\section{Recommendations}

$\mathrm{I}$

$\mathrm{n}$ line with the intention of planning new and better researches, it is necessary to point out the limitations of the present study. On one hand, it is worth to have a greater number of research participants since the sample was comprised of 15 persons per group. Besides, it would be relevant to integrate an active control group in order to associate the results to the direct effects of $\mathrm{MT}$, rather than associating these results to a consequence of the mere participation in a social activity.

On the other hand, the imbalance between men and women stands out, with a higher percentage of women participating. On this issue, data gathering was carried out in day centers that offer activities for older adults which have a greater participation of women, a pattern that seems to replicate across the world. In this point, there is a tendency to find more participation of female older adults in social proposals (25); this could be the cause of this imbalance in our study and in other.

Following authors that have studied healthy aging and approaches of music therapy for older people, from a neurocognitive approach (3-15) it can be concluded that MT is now playing a relevant role in working with elderly, thus contributing to the health promotion and prevention policies in order to improve life expectancy and quality of life for this population (2). It should be borne in mind that music therapy practiced by trained professionals is an alternative with multiple advantages when selecting musical resources for conducting optimal and effective interventions, according to the needs and/or requirements of the individuals aiming at contributing to a heathy aging.

\section{Author Contribution}

eronika Diaz Abrahan gathered and analyzed data, projected the article and reviewed it. Monitoring of data gathering and capture, as well as data analysis, article projection and 
review were carried out by Nadia Justel. Anahí Lemos Jaramillo contributed in data gathering and capture.

\section{Conflict of Interests}

$\mathrm{N}^{\text {meredaimad }}$

\section{References}

1. Redondo N. Composición por edades y envejecimiento demográfico. En: Torrado S, comp. Población y bienestar en la Argentina del primero al segundo centenario. Buenos Aires: Edhasa; 2007.

2. Organización de las Naciones Unidas (onu). Informe de la Segunda Asamblea Mundial sobre Envejecimiento. Nueva York: United Nations; 2002.

3. Mercadal Brotons M, Augé PM. Manual de musicoterapia en geriatría y demencias. Barcelona: Monsa-Prayma; 2008.

4. Zarebski G. Diversidad en la psicogerontología. En: Actas de las II Jornadas de Geriatría y Gerontología: Sonido, Salud y Vejez. Buenos Aires: Asociación Argentina de Musicoterapia; 2010 .

5. Mateos Hernández LA, Moral Marcos MT, San Romualdo Corral B. Sistema de evaluación musicoterapéutica para personas con enfermedad de Alzheimer y otras demencias. Madrid: Universidad Pontificia de Salamanca-Imserso; 2012.

6. Barrera DL, Donolo D. Diagnóstico diferencial de envejecimiento patológico. Desempeños en el Addenbrooke’s Cognitive Examination (ACE). Pensamiento Psicológico. 2009;5(12):45-58.

7. Erickson KI, et al. Exercise training increases size of hippocampus and improves memory. Proc Natl Acad Sci USA. 2011;108(7):3017-22. Doi: 10.1073/pnas.1015950108

8. Foubert-Samier A, et al. Education, occupation, leisure activities, and brain reserve: a population-based study. Neurobiology of Aging. 2010;33(2);423. Doi: 10.1016/j.neurobiolaging.2010.09.023

9. Evans DA, et al. Level of education and change in cognitive function in a community population of older persons. Ann Epidemiol. 1993;3(1):71-7. Doi: 10.1016/10472797(93)90012-S

10. Seinfeld S, Figueroa H, Ortiz-Gil J, Sánchez-Vives M. Effects of music learning and piano practice on cognitive function, mood and quality of life in older adults. Front Psychol. 2013;1(4):810. Doi: 10.3389/fpsyg.2013.00810

11. Gómez-Romero M, Jiménez-Palomares M, Rodríguez-Mansilla J, Flores-Nieto A, GarridoArdila EM, Gonzales MV. Beneficios de la musicoterapia a las alteraciones conductuales de la demencia. Revisión sistemática. Neurología. 2017;32(4):253-63. Doi: 10.1016/j. nrl.2014.11.001 
12. Sánchez Guío T, Barranco Obis P, Millán Vicente A, Fornies Baquedano M. La musicoterapia como indicador de mejora de la calidad de vida en un envejecimiento activo. Metas de Enfermería. 2017;20(7):24-31.

13. Ceccato E, et al. stam protocol in dementia: a multicenter, single-blind, randomized, and controlled trial. Am J Alzheimers Dis Other Demen. 2012;27(5):301-10. Doi: $10.1177 / 1533317512452038$

14. Choi AN, Lee MS, Cheong KJ, Lee JS. Effects of group music intervention on behavioral and psychological symptoms in patients with dementia: a pilot-controlled trial. Int J Neurosci. 2009;119(4):471-81. Doi: 10.1080/00207450802328136

15. Gómez Gallego M, Gómez García J. Musicoterapia en la enfermedad de Alzheimer: efectos cognitivos, psicológicos y conductuales. Neurología. 2001;32(5):300-8. Doi: 10.1016/j. $\operatorname{nrl} .2015 .12 .00$

16. Raglio A, Bellandi D, Baiardi P, Gianotti M, Ubezio MC, Granieri E. Listening to music and active music therapy in behavioral disturbances in dementia: a crossover study. J Am Geriatr Soc. 2013;61(4):645-7. Doi: 10.1111/jgs.12187

17. Raglio A, et al. Effect of active music therapy and individualized listening to music on dementia: a multicenter randomized controlled trial. J Am Geriatr Soc. 2015;63(8):15349. Doi: 10.1111/jgs.13558

18. Zhang Y, et al. Does music therapy enhance behavioral and cognitive function in elderly dementia patients? A systematic review and meta-analysis. Ageing Res Rev. 2017;35:111. Doi: $10.1016 /$ j.arr.2016.12.003

19. Asamblea Médica Mundial. Declaración de Helsinki de la Amm - Principios éticos para las investigaciones médicas en seres humanos. Retrieved on 2018.10.3. Disponible en: // www.wma.net/es/policies-post/declaracion-de-helsinki-de-la-amm-principios-eticos-para-las-investigaciones-medicas-en-seres-humanos/

20. Mikulic IM, Muiños R. La construcción y uso de instrumentos de evaluación en la investigación e intervención psicológica: el inventario de calidad de vida percibida (Icv). Anuario de Investigaciones. 2005;12:193-202.

21. Peraza-Chil E, Zaldívar-Pérez DF. La musicoterapia. Un nuevo enfrentamiento al estrés y la hipertensión arterial. Revista Cubana de Psicología. 2003;20:10-23.

22. Kokal I, Engel A, Kirschner S, Keysers C. Synchronized drumming enhances activity in the caudate and facilitates prosocial commitment. If the rhythm comes easily. PLoS One. 2011;6(11):e27272. Doi: 10.1371/journal.pone.0027272

23. Insel TR. The challenge of translation in social neuroscience: a review of oxytocin, vasopressin, and affiliative behavior. Neuron. 2010;65(6):768-79. Doi: 10.1016/j.neuron.2010.03.005

24. Ukkola-Vuoti L, Oikkonen J, Onkamo P, Karma K, Raijas P, Järvelä I. Association of the arginine vasopressin receptor 1a (avpr1a) haplotypes with listening to music. J Hum Genet. 2011;56(4):324-9. Doi: 10.1038/jhg.2011.13

25. Hanna-Pladdy B, Gajewski B. Recent and past musical activity predicts cognitive aging variability: direct comparison with general lifestyle activities. Front Hum Neurosci. 2012;6:198. Doi: 10.3389/fnhum.2012.00198 